\title{
High-quality-draft genome sequence of the multiple heavy metal resistant bacterium Pseudaminobacter manganicus $\mathrm{JH}-7^{\top}$
}

\author{
Xian $\mathrm{Xia}^{\dagger}$, Jiahong $\mathrm{Li}^{\dagger}$, Zijie Zhou, Dan Wang, Jing Huang and Gejiao Wang
}

\begin{abstract}
Pseudaminobacter manganicus JH-7 $7^{\top}$ (= KCTC $52258^{\top}=$ CCTCC AB 2016107 ${ }^{\top}$ ) is a Gram-staining-negative, aerobic and non-motile strain that was isolated from a manganese mine. The strain $\mathrm{JH}-\mathrm{T}^{\top}$ shows multiple heavy metal resistance and can effectively remove $\mathrm{Mn}^{2+}$ and $\mathrm{Cd}^{2+}$. In addition, it is able to produce exopolysaccharides (EPS), which may contribute to metal remove/adsorption. Thus, strain $\mathrm{JH}-7^{\top}$ shows a great potential in bioremediation of heavy metal-contaminated environment. In this study, we report the draft genomic sequence of $P$. manganicus $\mathrm{JH}-7^{\top}$ and compare it to related genomes. Strain $\mathrm{JH}-7^{\top}$ has a 4,842,937 bp genome size with a $\mathrm{G}+\mathrm{C}$ content of $61.2 \%$, containing 4504 protein-coding genes and 71 RNA genes. A large number of putative genes associated with heavy metal resistance and EPS synthesis are found in the genome.
\end{abstract}

Keywords: Cadmium, Exopolysaccharides, Heavy metal resistance and adsorption, Manganese,Pseudaminobacter

\section{Introduction}

Genus Pseudaminobacter was established by Kämpfer et al. in 1999 and contains three species represented by Pseudaminobacter salicylatoxidans $\mathrm{BN}^{2} 2^{\mathrm{T}}$ (type species) [1], Pseudaminobacter defluvii THI $051^{\mathrm{T}}$ [1] and Pseudaminobacter manganicus $\mathrm{JH}-7^{\mathrm{T}}$ [2]. The common characteristics of Pseudaminobacter strains are Gram-staining-negative, rod-shaped and aerobic $[1,2]$. P. salicylatoxidans $\mathrm{BN} 12^{\mathrm{T}}$ contains a peculiar ring-fission dioxygenase with the ability to cleave salicylate in 1,2-position to 2-oxohepta-3, 5-dienedioic acid [3].

P. manganicus $\mathrm{JH}-7^{\mathrm{T}}$ was isolated from a sludge sample of a wastewater ditch in Dalong manganese mine in 2015 [2]. It shows multiple heavy metal resistance and can effectively remove $\mathrm{Mn}^{2+}$ and $\mathrm{Cd}^{2+}$. In addition, the strain produces EPS, which may facilitate heavy metal resistance and adsorption [4-6]. These features show great interests because of its potential applications in bioremediation of heavy metal contaminated environments. So far, only the

\footnotetext{
* Correspondence: gejiao@mail.hzau.edu.cn

${ }^{\dagger}$ Xian Xia and Jiahong Li contributed equally to this work.

State Key Laboratory of Agricultural Microbiology, Huazhong Agricultural

University, Wuhan 430070, People's Republic of China
}

genome of an atypical Pseudaminobacter strain Pseudaminobacter salicylatoxidans KCT001 has been sequenced [7]. Strain KCT001 can utilize tetrathionate as the substrate for sulfur-oxidizing chemolithotrophic growth [8]. For better understanding the mechanism of bacterial resistance and removal of heavy metals, here we analyze the genome of $P$. manganicus $\mathrm{JH}-7^{\mathrm{T}}$.

\section{Organism information \\ Classification and features}

The phylogenetic relationship of $P$. manganicus $\mathrm{JH}-7^{\mathrm{T}}$ to the related members is shown in a $16 \mathrm{~S}$ rRNA gene based neighbor-joining tree. Strain $\mathrm{JH}-7^{\mathrm{T}}$ is closely related to $P$. salicylatoxidans $\mathrm{BN}^{\mathrm{T}}{ }^{\mathrm{T}}, P$. defluvii THI $051^{\mathrm{T}}$ and P. salicylatoxidans KCT001 (Fig. 1). Strain $\mathrm{JH}-7^{\mathrm{T}}$ is Gram-staining-negative, aerobic, non-motile and rod-shaped $(0.3-0.8 \times 1-2 \mu \mathrm{m})$ (Fig. 2). The colonies are white, circular, entire, slightly raised and smooth on LB agar plates. It is positive for oxidase and catalase activities and hydrolysis of casein [2]. The major fatty acids are $C_{18: 1}$ $\omega 7 c, \mathrm{C}_{19: 0}$ cyclo $\omega 8 c$ and $\mathrm{C}_{16: 0}$ and the $\mathrm{G}+\mathrm{C}$ content is $61.2 \mathrm{~mol} \%$ [2]. The major polyamine is sym-homospermidine and the respiratory quinone is

(c) The Author(s). 2018 Open Access This article is distributed under the terms of the Creative Commons Attribution 4.0 International License (http://creativecommons.org/licenses/by/4.0/), which permits unrestricted use, distribution, and 


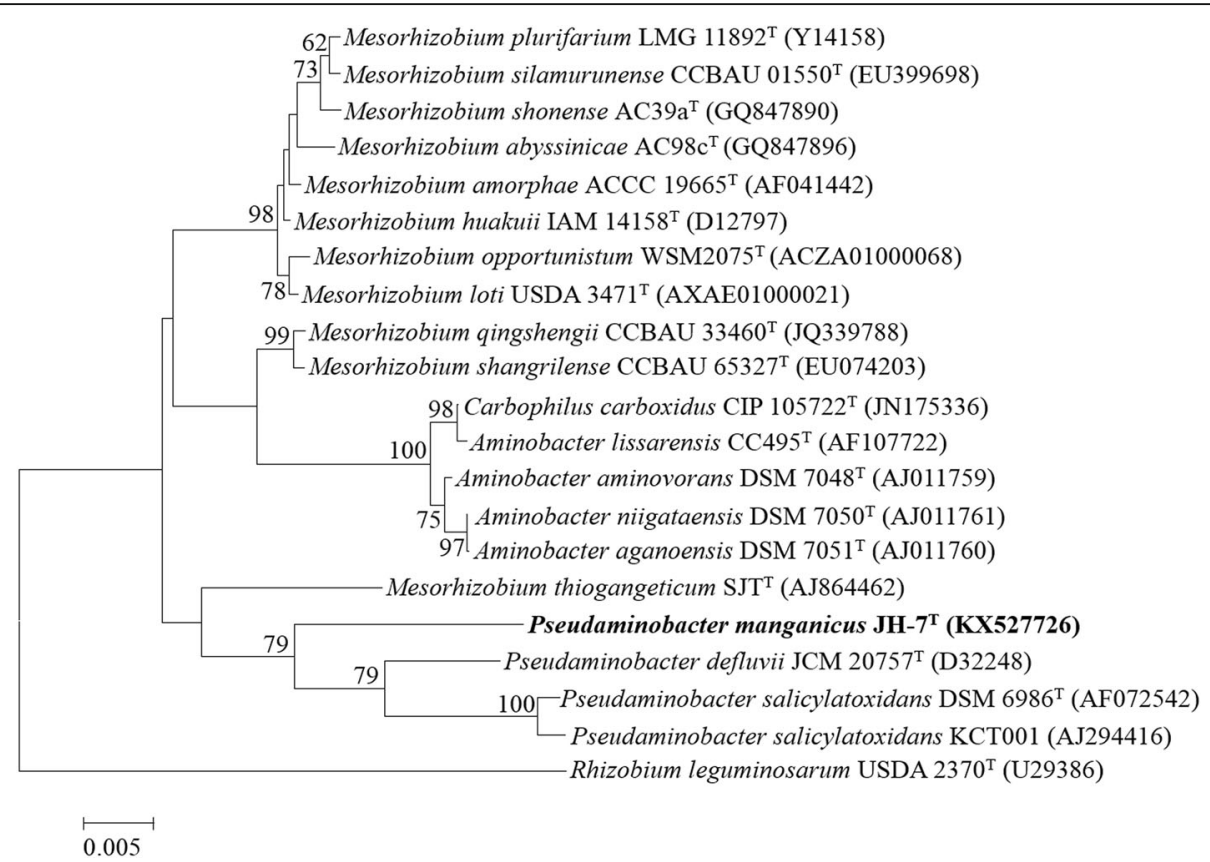

Fig. 1 Phylogenetic tree highlighting the phylogenetic position of Pseudaminobacter manganicus $\mathrm{JH}-7^{\top}$. The phylogenetic tree was constructed based on the 16S rRNA gene sequences. The analysis was inferred by MEGA 6.0 [41] with neighbor-joining algorithm and 1000 bootstrap repetitions were computed to estimate the reliability of the tree. Bar, 0.005 substitutions per nucleotide position

ubiquinone-10. The polar lipids are phosphatidylmonomethylethanolamine, diphosphatidylglycerol, phosphatidylglycerol, phosphatidylcholine, two aminolipids and two lipids [2]. Table 1 shows the general features of $P$. manganicus $\mathrm{JH}-7^{\mathrm{T}}$.

The resistant levels of $P$. manganicus $\mathrm{JH}-7^{\mathrm{T}}$ to multiple metal(loid)s were tested with the MIC on LB agar

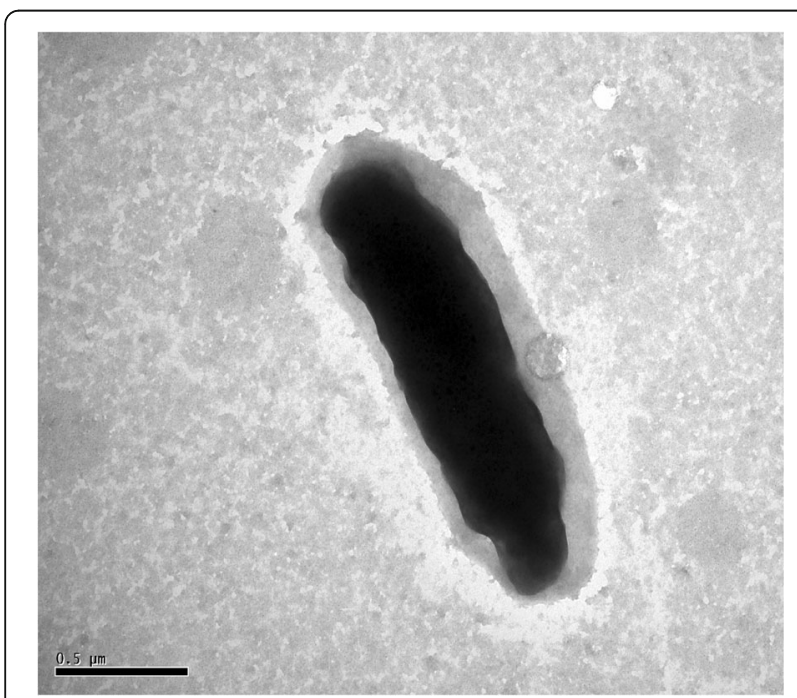

Fig. 2 Transmission electron micrograph image of strain $\mathrm{JH}-7^{\top}$. Bar, $0.5 \mu \mathrm{m}$ plates incubated at $28{ }^{\circ} \mathrm{C}$ for 7 days. The MICs for $\mathrm{MnCl}_{2}, \mathrm{CdCl}_{2}, \mathrm{PbCl}_{2}, \mathrm{CuCl}_{2}, \mathrm{ZnSO}_{4}$ and $\mathrm{NiSO}_{4}$ are100, 2, $10,5,5$ and $5 \mathrm{mmol} / \mathrm{L}$ respectively. The MICs for $\mathrm{K}_{2} \mathrm{CrO}_{4}$ and $\mathrm{Na}_{3} \mathrm{AsO}_{3}$ are both $0.1 \mathrm{mmol} / \mathrm{L}$ that are lower than the above six metals. Specifically, strain $\mathrm{JH}-7^{\mathrm{T}}$ could remove nearly $60 \%$ of $5 \mathrm{mmol} / \mathrm{L} \mathrm{Mn}^{2+}$ and nearly $80 \%$ of $0.1 \mathrm{mmol} / \mathrm{L} \mathrm{Cd}^{2+}$ (Fig. 3), respectively. In addition, strain $\mathrm{JH}-7^{\mathrm{T}}$ could produce EPS based on the aniline blue reaction incubated on LB agar in 3-7 days [9] (data not shown). This phenomenon is consistent with the cell image observed by TEM (Fig. 2). A lay of shadow around the strain was similar to the EPS observed in strain Bifidobacterium longum 35,624 [10].

\section{Genome sequencing information}

\section{Genome project history}

This organism was selected for sequencing particularly due to its multiple heavy metals resistance and heavy metal removal ability. Genome sequencing was performed by Wuhan Bio-Broad Co., Ltd., Wuhan, China in 2016. The draft genome sequence of strain $P$. manganicus $\mathrm{JH}-7^{\mathrm{T}}$ has been deposited at DDBJ/EMBL/GenBank under accession number MDET00000000. The project information is summarized in Table 2.

\section{Growth conditions and genomic DNA preparation}

P. manganicus $\mathrm{JH}-7^{\mathrm{T}}$ was grown under aerobic conditions in LB medium at $28{ }^{\circ} \mathrm{C}$ for $40 \mathrm{~h}$. DNA extraction 
Table 1 Classification and general features of $P$. manganicus $\mathrm{JH}-7^{\top}$ [42]

\begin{tabular}{|c|c|c|c|}
\hline$\overline{M I G S ~ I D ~}$ & Property & Term & Evidence code \\
\hline & Classification & Domain Bacteria & TAS [43] \\
\hline & & Phylum Proteobacteria & TAS $[44,45]$ \\
\hline & & Class Alphaproteobacteria & TAS [46] \\
\hline & & Order Rhizobiales & $\operatorname{TAS}[46,47]$ \\
\hline & & Family Phyllobacteriaceae & $\operatorname{TAS}[46,47]$ \\
\hline & & Genus Pseudaminobacter & $\operatorname{TAS}[1,2]$ \\
\hline & & Species manganicus & TAS [2] \\
\hline & & Type strain JH-7 ${ }^{\top}\left(=\right.$ KCTC $52258^{\top}=$ CCTCC AB 2016107 $\left.7^{\top}\right)$ & TAS [2] \\
\hline & Gram stain & negative & TAS [2] \\
\hline & Cell shape & rod-shaped & TAS [2] \\
\hline & Motility & no & TAS [2] \\
\hline & Sporulation & no & TAS [2] \\
\hline & Temperature range & $15-40{ }^{\circ} \mathrm{C}$ & TAS [2] \\
\hline & Optimum temperature & $28^{\circ} \mathrm{C}$ & TAS [2] \\
\hline & $\mathrm{pH}$ range; Optimum & $5-9 ; 7$ & TAS [2] \\
\hline & Carbon source & D-glucose, L-arabinose, D-fructose and D-mannose & TAS [2] \\
\hline MIGS-6 & Habitat & Mine sludge & TAS [2] \\
\hline MIGS-6.3 & Salinity & $0-6 \% \mathrm{NaCl}(w / v)$ & TAS [2] \\
\hline MIGS-22 & Oxygen requirement & aerobic & TAS [2] \\
\hline MIGS-15 & Biotic relationship & free-living & TAS [2] \\
\hline MIGS-14 & Pathogenicity & non-pathogen & NAS \\
\hline MIGS-4 & Geographic location & Tongren city, Guizhou province, P. R. China & TAS [2] \\
\hline MIGS-5 & Sample collection & 2015 & TAS [2] \\
\hline MIGS-4.1 & Latitude & $\mathrm{N} 27^{\circ} 43^{\prime} 8^{\prime \prime}$ & TAS [2] \\
\hline MIGS-4.2 & Longitude & $\mathrm{E} 108^{\circ} 31^{\prime} 42^{\prime \prime}$ & TAS [2] \\
\hline MIGS-4.4 & Altitude & not reported & \\
\hline
\end{tabular}

These evidence codes are from the Gene Ontology project [48]

IDA Inferred from Direct Assay, TAS Traceable Author Statement (i.e., a direct report exists in the literature), NAS Non-traceable Author Statement (i.e., not directly observed for the living, isolated sample, but based on a generally accepted property for the species, or anecdotal evidence)

${ }^{\mathrm{a}}$ Evidence codes
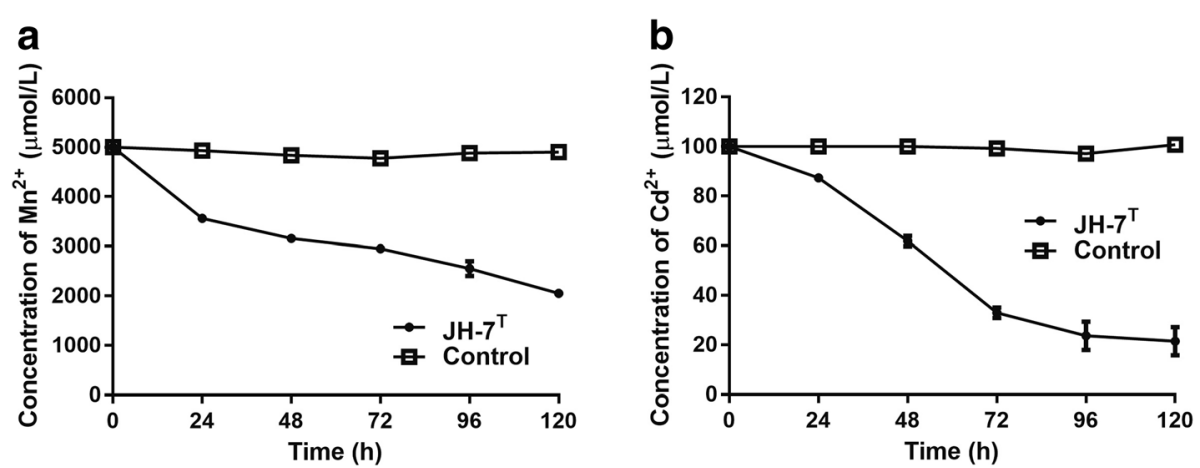

Fig. $3 \mathrm{Mn}^{2+}$ and $\mathrm{Cd}^{2+}$ removed by P. manganicus $\mathrm{JH}-7^{\top}$. Control stands for null LB medium. Strain $\mathrm{JH}-7^{\top}$ was incubated until $\mathrm{OD}_{600}$ reach 1.0, and then amended with $5000 \mu \mathrm{mol} / \mathrm{L} \mathrm{MnCl}_{2}$ (a) and $100 \mu \mathrm{mol} / \mathrm{L} \mathrm{CdCl}_{2}$ (b), respectively. The cultures were removed at $24 \mathrm{~h}$ intervals. After centrifuging at $12,000 \mathrm{rpm}$ for $10 \mathrm{~min}$, the supernatant was used to determine the residual concentration of $\mathrm{Mn}^{2+}$ and $\mathrm{Cd}^{2+}$ by the atomic absorption spectrometry AAS (AAS; 986A, Beijing Puxi General Instrument 197 Co., Beijing, China). Bars represent the mean \pm SD of three biological replicates 
Table 2 Project information

\begin{tabular}{|c|c|c|}
\hline MIGS ID & Property & Term \\
\hline MIGS-31 & Finishing quality & High-quality draft \\
\hline MIGS-28 & Libraries used & $\begin{array}{l}\text { Illumina Paired-End library (300 bp in- } \\
\text { sert size) }\end{array}$ \\
\hline MIGS-29 & $\begin{array}{l}\text { Sequencing } \\
\text { platforms }\end{array}$ & Illumina Miseq 2000 \\
\hline $\begin{array}{l}\text { MIGS- } \\
31.2\end{array}$ & Fold coverage & $624.94 x$ \\
\hline MIGS-30 & Assemblers & SOAPdenovo v2.04 \\
\hline \multirow[t]{6}{*}{ MIGS-32 } & Gene calling method & GeneMarkS $^{+}$ \\
\hline & Locus TAG & BFN67 \\
\hline & Genbank ID & MDET00000000 \\
\hline & $\begin{array}{l}\text { Genbank Date of } \\
\text { Release }\end{array}$ & 31, March, 2017 \\
\hline & GOLD ID & Gp0291525 \\
\hline & Bioproject & PRJNA338732 \\
\hline \multirow[t]{2}{*}{ MIGS-13 } & $\begin{array}{l}\text { Source material } \\
\text { identifier }\end{array}$ & CСТCC AB $2016107^{\top}$ \\
\hline & Project relevance & Bioremediation \\
\hline
\end{tabular}

was performed using the QiAamp kit (Qiagen, Germany) as the manufacturer's instructions. A NanoDrop Spectrophotometer 2000 was used to determine the quality and quantity of the DNA. Seven microgram of DNA was sent to Bio-broad Technogoly Co., Ltd., Wuhan, China for sequencing.

Table 3 Genome statistics

\begin{tabular}{lrr}
\hline Attribute & \multicolumn{1}{c}{ Value } & \% of total \\
\hline Genome size (bp) & $4,842,937$ & 100 \\
DNA coding (bp) & $4,238,496$ & 87.5 \\
DNA G + C (bp) & $2,963,726$ & 61.2 \\
DNA scaffolds & 60 & 100 \\
Total genes ${ }^{b}$ & 4685 & 100 \\
Protein-coding genes & 4504 & 96.2 \\
RNA genes & 71 & 1.7 \\
Pseudo genes & 110 & 2.3 \\
Genes in internal clusters & 1725 & 38.3 \\
Genes with function prediction & 3228 & 68.9 \\
Genes assigned to COGs & 3729 & 79.6 \\
Genes with Pfam domains & 3926 & 83.8 \\
Genes with signal peptides & 392 & 8.4 \\
Genes with transmembrane helices & 1119 & 23.9 \\
CRISPR repeats & 5 & \\
\hline
\end{tabular}

${ }^{a}$ The total is based on either the size of the genome in base pairs or the total number of protein coding genes in the annotated genome

${ }^{\mathrm{b}}$ Also includes 110 pseudogenes, 54 tRNA genes, 12 rRNAs and 5 ncRNA

\section{Genome sequencing and assembly}

The genome of strain $\mathrm{JH}-7^{\mathrm{T}}$ was sequenced on Illumina Hiseq2000 [11] and assembled by Bio-broad Technogoly Co., Ltd., Wuhan using SOAPdenovo v2.04 [12]. An Illumina standard shotgun library was constructed and sequenced, which generated 19,404,755 reads totaling 2,885,684,230 bp and average of 625 times genome coverage. The total size of the genome is $4,842,937 \mathrm{bp}$ and a total of 60 scaffolds were obtained after arranging 68 contigs together. The part gaps of assembly were filled and the error bases were revised using GapCloser v1.12 [13].

\section{Genome annotation}

The draft genome was annotated through the NCBI Prokaryotic Genome Annotation Pipeline (PGAP), and

Table 4 Number of genes associated with the 25 general COG functional categories

\begin{tabular}{|c|c|c|c|}
\hline Code & Value & $\begin{array}{l}\% \text { of } \\
\text { total }^{a}\end{array}$ & Description \\
\hline J & 181 & 4.02 & Translation \\
\hline A & 0 & 0.00 & RNA processing and modification \\
\hline K & 299 & 6.64 & Transcription \\
\hline L & 233 & 5.17 & Replication, recombination and repair \\
\hline B & 3 & 0.07 & Chromatin structure and dynamics \\
\hline D & 39 & 0.87 & Cell cycle control, mitosis and meiosis \\
\hline Y & 0 & 0.00 & Nuclear structure \\
\hline V & 46 & 1.02 & Defense mechanisms \\
\hline $\mathrm{T}$ & 134 & 2.98 & Signal transduction mechanisms \\
\hline M & 217 & 4.82 & Cell wall/membrane biogenesis \\
\hline N & 35 & 0.78 & Cell motility \\
\hline Z & 0 & 0.00 & Cytoskeleton \\
\hline W & 0 & 0.00 & Extracellular structures \\
\hline U & 106 & 2.35 & Intracellular trafficking and secretion \\
\hline O & 156 & 3.46 & $\begin{array}{l}\text { Posttranslational modification, protein turnover, } \\
\text { chaperones }\end{array}$ \\
\hline C & 240 & 5.33 & Energy production and conversion \\
\hline G & 312 & 6.93 & Carbohydrate transport and metabolism \\
\hline$E$ & 482 & 10.70 & Amino acid transport and metabolism \\
\hline $\mathrm{F}$ & 87 & 1.93 & Nucleotide transport and metabolism \\
\hline H & 158 & 3.51 & Coenzyme transport and metabolism \\
\hline I & 153 & 3.40 & Lipid transport and metabolism \\
\hline P & 209 & 4.64 & Inorganic ion transport and metabolism \\
\hline Q & 91 & 2.02 & $\begin{array}{l}\text { Secondary metabolites biosynthesis, transport } \\
\text { and catabolism }\end{array}$ \\
\hline $\mathrm{R}$ & 453 & 10.06 & General function prediction only \\
\hline$S$ & 444 & 9.86 & Function unknown \\
\hline- & 775 & 17.21 & Not in COGs \\
\hline
\end{tabular}

${ }^{a}$ The total is based on the total number of protein coding genes in the annotated genome 
genes were identified using the gene caller GeneMarkS ${ }^{+}$ with the similarity-based gene detection approach [14]. The predicted CDSs were translated and were submitted to the Pfam protein family database [15] and KEGG database [16]. The genes in internal clusters were performed by OrthoMCL $[17,18]$. The protein function classification, transmembrane helices and signal peptides were predicted by WebMGA [19], TMHMM v. 2.0 [20] and SignalP 4.1 [21], respectively. In addition, the CRISPRfinder program [22] was used to predict CRISPRs in the genome.

\section{Genome properties}

The draft genome size of strain $\mathrm{JH}-7^{\mathrm{T}}$ is $4,842,937 \mathrm{bp}$ with $61.2 \mathrm{~mol} \% \mathrm{G}+\mathrm{C}$ content and contains 60 scaffolds. The genome properties and statistics are shown in Table 3. From a total of 4685 genes, 4504 (96.2\%) are protein coding genes, $110(2.3 \%)$ are pseudo genes and the rest are 71 predicted RNA genes, including $54 \mathrm{tRNA}$, 12 rRNAs and 5 ncRNA. In addition, 3729 (82.8\%) protein coding genes are distributed into COG functional categories (Table 4).

\section{Insights from the genome sequence}

Strain $\mathrm{JH}-7^{\mathrm{T}}$ could tolerant multiple heavy metals $\left(\mathrm{Mn}^{2+}\right.$, $\mathrm{Cd}^{2+}, \mathrm{Pb}^{2+}, \mathrm{Cu}^{2+}, \mathrm{Zn}^{2+}$ and $\mathrm{Ni}^{2+}$ ) and remove $\mathrm{Mn}^{2+}$ and $\mathrm{Cd}^{2+}$, suggesting that it has developed a number of evolutionary strategies to adapt the mine environment. According to the genome annotation results, strain $\mathrm{JH}-7^{\mathrm{T}}$ harbors various putative proteins related to heavy metal(loid)s resistance including transporters, resistance proteins and metal reductases (Additional file 1: Table S1). MntH [23] and metal ABC transport system [24] are involved in cation uptake. Heavy metal-transporting ATPase is responsible for the efflux of $\mathrm{Pb}^{2+}, \mathrm{Zn}^{2+}, \mathrm{Cd}^{2+}$ and $\mathrm{Ni}^{2+}[25-28]$. The genome contains $\mathrm{Cu}^{2+}$ efflux system CopABC [29], mercuric reductase MerA and regulator MerR [30]. Athough the MICs for $\mathrm{Cr}^{6+}$ and $\mathrm{As}^{3+}$ are not high, the $\mathrm{Cr}^{6+}$ efflux protein $\mathrm{ChrA}[27,31]$ and $\mathrm{As}^{3+}$ resistant proteins (ArsRHC and ACR3) [32-34] are present.

EPS are long-chain polysaccharides consisting of branched, repeating units of sugars or sugar derivatives [35]. Stain $\mathrm{JH}-7^{\mathrm{T}}$ could produce EPS and all essential proteins for EPS production are found in the genome.

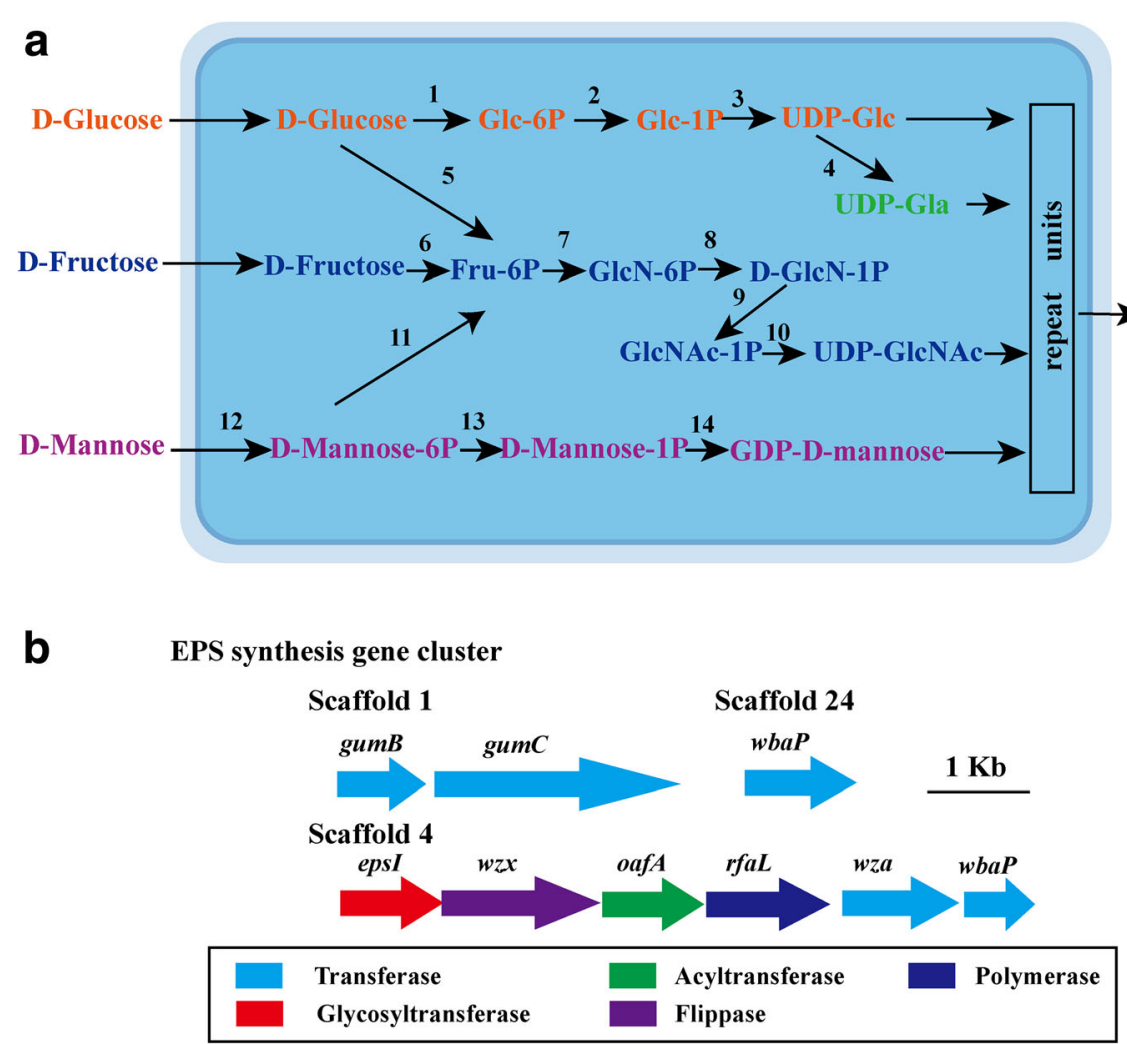

Fig. 4 Putative nucleotide sugars biosynthesis pathway and EPS synthesis gens in P. manganicus $\mathrm{JH}-7^{\top}$. a The predicted nucleotide sugars biosynthesis pathway. The numbers refer to the enzymes involved: 1, Glucokinase; 2, a-D-glucose phosphate-specific phosphoglucomutase; 3 , UTP--glucose-1-phosphate uridylyltransferase; 4, UDP-glucose 4-epimerase GalE; 5, Glucose-6-phosphate isomerase; 6, Fructokinase; 7, Glutamine-fructose-6-phosphate aminotransferase; 8, Phosphoglucosamine mutase; 9, UDP-N-acetylglucosamine; 10, Glucose-6-phosphate isomerase; 11, Mannose-6-phosphate isomerase; 12, PTS-Man-EIIA, ManX; 13, Phosphoglucomutase; 14, Mannose-1-phosphate guanylyltransferase. b The EPS synthesis gene cluster in strain $\mathrm{JH}-7^{\top}$ 


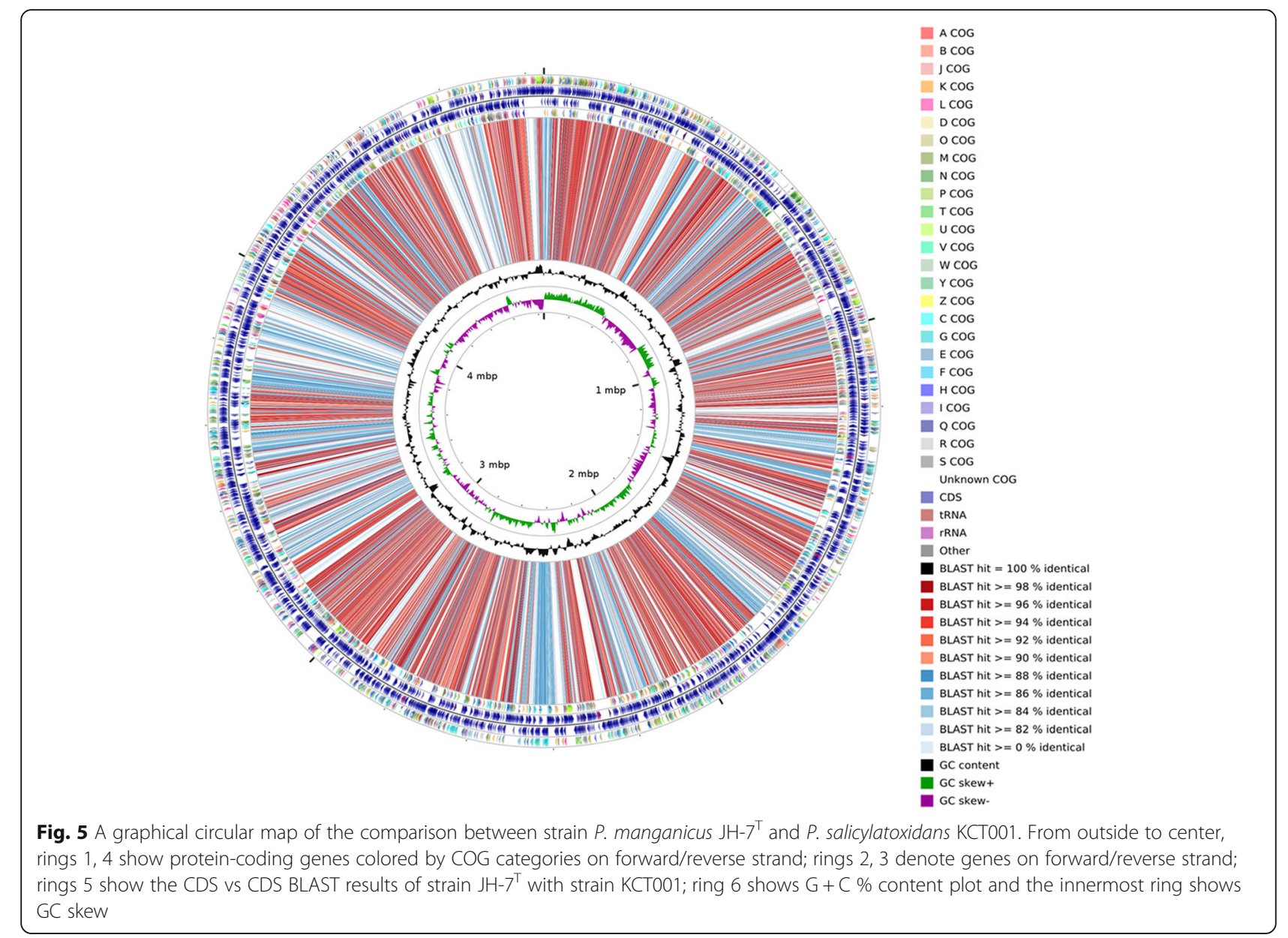

Four complete nucleotide sugar synthesis (EPS precursor) pathways are identified based on KEGG analysis (Additional file 1: Table S2) including the syntheses of UDP-glucose, UDP-galactose, UDP-GlcNAc and GDP-D-mannose (Fig. 4a). EPS assembly gene clusters were also found in the genome of strain $\mathrm{JH}-7^{\mathrm{T}}$ [36] (Additional file 1: Table S3, Fig. 4b). Based on gene analysis, it is suggested that the EPS assembly in strain $\mathrm{JH}-7^{\mathrm{T}}$ might belong to $\mathrm{Wzx} / \mathrm{Wzy}$-dependent pathway [37], e.g., repeat units are assembled by glycosyltransferases (EpsI) and translocated across the cytoplasmic membrane to periplasm by flippase (Wzx) [37] and WbaP [38]. Next, Wzy (RfaL), polysaccharide co-polymerase (GumC) and the outer membrane polysaccharide exporter (GumB) transports the polymerized repeat units to cell surface $[37,39]$. EPS has been reported to contribute to heavy metal removal/adsorption in bacteria [3-6]. Hence, the ability of EPS may contribute to $\mathrm{Mn}^{2+}$ and $\mathrm{Cd}^{2+}$ removal.

To gain more insight, the genomic features of strain $\mathrm{JH}-7^{\mathrm{T}}$ is compared with the available genome P. salicylatoxidans $\mathrm{KCT} 001$ [7]. Strain $\mathrm{JH}-7^{\mathrm{T}}$ has similar genome size (4.84 Mbp) and $\mathrm{G}+\mathrm{C}$ content $(61.2 \mathrm{~mol} \%)$ compared to strain KCT001 (4.61 Mbp; $62.8 \mathrm{~mol} \%$ ). A total of 2408 core proteins are shared between the two strains. Strain $\mathrm{JH}-7^{\mathrm{T}}$ has 1724 strain-specific CDSs. Figure 5 shows the genome comparison results of strain $\mathrm{JH}-7^{\mathrm{T}}$ and strain KCT001 using CGview comparison tool [40]. Comparing to P. salicylatoxidans KCT001, strain $\mathrm{JH}-7^{\mathrm{T}}$ was unable to utilize tetrathionate for chemolithoautotrophy (data not shown). However, it harbors high quantitative and diverse heavy metal resistance genes.

\section{Conclusions}

To the best of our knowledge, this study provides the first typical strain genomic information of the genus Pseudaminobacter and revealed a consistency of important characters between genotypes and phenotypes. Strain $\mathrm{JH}-7^{\mathrm{T}}$ is resistant to multiple heavy metals and capable of removal $\mathrm{Mn}^{2+} / \mathrm{Cd}^{2+}$. Genome analysis reveal various genes responsible for multiple heavy metal resistance, which provides the genomic basis for this strain to adapt the harmful environment. 


\section{Additional file}

Additional file 1: Table S1. Putative heavy metal(loid)s resistance proteins. Table S2. Putative nucleotide sugars biosynthesis proteins for EPS production. Table S3. Putative proteins for EPS production. (XLSX $11 \mathrm{~kb}$ )

\section{Abbreviations}

EPS: Exopolysaccharides; MIC: Minimal inhibition concentration

\section{Funding}

This study was supported by National key research and development program of China (2016YFD0800702)

\section{Authors' contributions}

$X X$ and $\lrcorner L$ performed the sequence annotation and genomic analysis and prepared the draft manuscript. ZZ, DW and JH performed the heavy metals resistance and removal tests. GW designed the study and revised the manuscript. All authors read and approved the final manuscript.

\section{Competing interests}

The authors declare that they have no competing interests.

\section{Publisher's Note}

Springer Nature remains neutral with regard to jurisdictional claims in published maps and institutional affiliations.

\section{Received: 10 January 2018 Accepted: 28 September 2018}

Published online: 25 October 2018

\section{References}

1. Kämpfer P, Müller C, Mau M, Neef A, Auling G, Busse HJ, et al. Description of Pseudaminobacter gen. Nov. with two new species, Pseudaminobacter salicylatoxidans sp. nov. and Pseudaminobacter defluvii sp. nov. Intl J Syst Bacteriol. 1999;149:887-97.

2. $\quad$ Li J, Huang J, Liao S, Wang G. Pseudaminobacter manganicus sp. nov., isolated from sludge of a manganese mine. Int J Syst Evol Microbiol. 2017;67(5):1589-94.

3. Hintner JP, Lechner C, Riegert U, Kuhm AE, Storm T, Reemtsma T, et al. Direct ring fission of salicylate by a salicylate 1,2-dioxygenase activity from Pseudaminobacter salicylatoxidans. J Bacteriol. 2001;183(23):6936-42.

4. Natalia N, Bogino PC, Banchio E, Giordano W. Roles of extracellular polysaccharides and biofilm formation in heavy metal resistance of rhizobia. Materials. 2016:9(6):418.

5. Bhunia B, Prasad Uday US, Oinam G, Mondal A, Bandyopadhyay TK, Tiwari ON. Characterization, genetic regulation and production of cyanobacterial exopolysaccharides and its applicability for heavy metal removal. Carbohydr Polym. 2018;179:228-43.

6. Nouha K, Kumar RS, Tyagi RD. Heavy metals removal from wastewater using extracellular polymeric substances produced by Cloacibacterium normanense in wastewater sludge supplemented with crude glycerol and study of extracellular polymeric substances extraction by different methods. Bioresour Technol. 2016;212:120-9.

7. Alam M, Roy C, Pyne P, Agarwal A, George A, Ghosh W. Whole-genome shotgun sequence of the sulfur-oxidizing chemoautotroph Pseudaminobacter salicylatoxidans KCT001. J Bacteriol. 2012;194(17):4743-4.

8. Deb C, Stackebrandt E, Pradella S, Saha A, Roy P. Phylogenetically diverse new sulfur chemolithotrophs of a-proteobacteria isolated from Indian soils. Curr Microbiol. 2004:48(6):452-8.

9. Nagaraj K, Rekha PD, Arun AB. Exopolysaccharide produced by Enterobacter sp. YG4 reduces uranium induced nephrotoxicity. Int J Biol Macromol. 2016;82:557-61.

10. Altmann F, Kosma P, O'Callaghan A, Leahy S, Bottacini F, Molloy E, et al. Genome analysis and characterisation of the exopolysaccharide produced by Bifidobacterium longum subsp. longum 35624 ${ }^{\text {TM }}$. PLoS One. 2016;11(9): e0162983.

11. Bennett S. Solexa Ltd. Pharmacogenomics. 2004:5:433-8.

12. Luo R, Liu B, Xie Y, Li Z, Huang W, Yuan J, et al. SOAPdenovo2: an empirically improved memory-efficient short-read de novo assembler. Gigascience. 2012;1(1):18.
13. Li R, Zhu H, Ruan J, Qian W, Fang X, Shi Z, et al. De novo assembly of human genomes with massively parallel short read sequencing. Genome Res. 2010;20(2):265-72.

14. Besemer J, Lomsadze A, Borodovsky M. GeneMarkS: a self-training method for prediction of gene starts in microbial genomes. Implications for finding sequence motifs in regulatory regions. Nucleic Acids Res. 2001;29:2607-18.

15. Finn RD, Coggill P, Eberhardt RY, Eddy SR, Mistry J, Mitchell AL, et al. The Pfam protein families database: towards a more sustainable future. Nucleic Acids Res. 2016:44(1):279-85.

16. Kanehisa M, Goto S, Kawashima S, Okuno Y, Hattori M. The KEGG resource for deciphering the genome. Nucleic Acids Res. 2004;32:277-80.

17. Li L, Stoeckert CJ Jr, Roos DS. OrthoMCL: identification of ortholog groups for eukaryotic genomes. Genome Res. 2003;13(9):2178.

18. Fischer S, Brunk BP, Chen F, Gao X, Harb OS, lodice JB, et al. Using OrthoMCL to assign proteins to OrthoMCL-DB groups or to cluster proteomes into new ortholog groups. Curr Protoc Bioinformatics. 2011;36(1).

19. Wu S, Zhu Z, Fu L, Niu B, Li W. WebMGA: a customizable web server for fast metagenomic sequence analysis. BMC Genomics. 2011;12:444.

20. Krogh A, Larsson BË, Von Heijne G, Sonnhammer EL. Predicting transmembrane protein topology with a hidden Markov model: application to complete genomes. J Mol Biol. 2001;305:567-80.

21. Petersen TN, Brunak S, Von HG, Nielsen H. SignalP 4.0: discriminating signal peptides from transmembrane regions. Nat Methods. 2011:8(10):785-6.

22. Grissa I, Vergnaud G, Pourcel C. CRISPRFinder: a web tool to identify clustered regularly interspaced short palindromic repeats. Nucleic Acids Res. 2007;35:52-7.

23. Kehres DG, Zaharik ML, Finlay BB, Maguire ME. The NRAMP proteins of Salmonella typhimurium and Escherichia coli are selective manganese transporters involved in the response to reactive oxygen. Mol Microbiol. 2000:36(5):1085-100

24. Gabbianelli R, Scotti R, Ammendola S, Petrarca P, Nicolini L, Battistoni A. Role of ZnuABC and ZinT in Escherichia coli O157: H7 zinc acquisition and interaction with epithelial cells. BMC Microbiol. 2011;11(1):36.

25. Sharma $R$, Rensing $C$, Rosen BP, Mitra $B$. The ATP hydrolytic activity of purified ZntA, a Pb (II)/cd (II)/Zn (II)-translocating ATPase from Escherichia coli. J Biol Chem. 2000;275(6):3873-8.

26. Nies DH, Silver $\mathrm{S}$. Ion efflux systems involved in bacterial metal resistances. J Ind Microbiol. 1995;14(2):186-99.

27. Xia X, Li J, Liao S, Zhou G, Wang H, Li L, et al. Draft genomic sequence of a chromate-and sulfate-reducing Alishewanella strain with the ability to bioremediate $\mathrm{Cr}$ and cd contamination. Stand Genomic Sci. 2016;11(1):48.

28. Xiong J, Li D, Li H, He M, Miller S, Yu L, et al. Genome analysis and characterization of zinc efflux systems of a highly zinc-resistant bacterium Comamonas testosteroni S44. Res Microbiol. 2011;162(7):671-9.

29. Adaikkalam V, Swarup S. Characterization of copABCD operon from a coppersensitive Pseudomonas putida strain. Can J Microbiol. 2005;51(3):209-16.

30. Nascimento AM, Chartone-Souza E. Operon mer: bacterial resistance to mercury and potential for bioremediation of contaminated environments. Genet Mol Res. 2003:2(1):92-101.

31. Viti C, Marchi E, Decorosi F, Giovannetti L. Molecular mechanisms of Cr (VI) resistance in bacteria and fungi. FEMS Microbiol Rev. 2014:38(4):633-59.

32. Li X, Zhang L, Wang G. Genomic evidence reveals the extreme diversity and wide distribution of the arsenic-related genes in Burkholderiales. PLoS One. 2014;9(3):e92236.

33. Kang YS, Shi Z, Bothner B, Wang G, McDermott TR. Involvement of the Acr3 and DctA anti-porters in arsenite oxidation in Agrobacterium tumefaciens $5 \mathrm{~A}$ Environ Microbiol. 2015;17(6):1950-62.

34. Kruger MC, Bertin PN, Heipieper HJ, Arsène-Ploetze F. Bacterial metabolism of environmental arsenic-mechanisms and biotechnological applications. Appl Microbiol Biotechnol. 2013;97(9):3827-41.

35. Cui Y, Xu T, Qu X, Hu T, Jiang X, Zhao C. New insights into various production characteristics of Streptococcus thermophilus strains. Int J Mol Sci. 2016;17(10):1701.

36. Wu Q, Tun HM, Leung FC, Shah NP. Genomic insights into high exopolysaccharide-producing dairy starter bacterium Streptococcus thermophilus ASCC 1275. Sci Rep. 2014:4:4974.

37. Schmid J, Sieber V, Rehm B. Bacterial exopolysaccharides: biosynthesis pathways and engineering strategies. Front Microbiol. 2015;6:496.

38. Schäffer C, Wugeditsch T, Messner P, Whitfield C. Functional expression of enterobacterial O-polysaccharide biosynthesis enzymes in Bacillus subtilis. Appl Environ Microbiol. 2002;68(10):4722-30. 
39. Klena JD, Pradel E, Schnaitman CA. Comparison of lipopolysaccharide biosynthesis genes rfaK, rfaL, rfaY, and rfaZ of Escherichia coli K-12 and Salmonella typhimurium. J Bacteriol. 1992;174(14):4746-52.

40. Grant JR, Arantes AS, Stothard P. Comparing thousands of circular genomes using the CGView comparison tool. BMC Genomics. 2012;13:202.

41. Tamura K, Stecher G, Peterson D, Filipski A, Kumar S. MEGA6: molecular evolutionary genetics analysis version 6.0. Mol Biol Evol. 2013;30(12):2725-9.

42. Field D, Garrity GM, Gray T, Morrison N, Selengut J, Sterk P, et al. The minimum information about a genome sequence (MIGS) specification. Nat Biotechnol. 2008;26:541-7. https://doi.org/10.1038/nbt1360 PMID: 18464787.

43. Woese CR, Kandler O, Weelis ML. Towards a natural system of organisms: proposal for the domains archaea, bacteria and eucarya. Proc Natl Acad Sci U S A. 1990;87:4576-9.

44. Garrity GM, Bell JA, Phylum Lilburn T. XIV. Proteobacteria phyl nov. In: Brenner DJ, Krieg NR, Stanley JT, Garrity GM, editors. Bergey's manual of Sytematic bacteriology, second edition. Vol. 2 (the Proteobacteria), part B the Gammaproteobacteria. New York: Springer; 2005. p. 1.

45. Stackebrandt E, Murray RGE, Trüper HG. Proteobacteria classis nov., a name for the phylogenetic taxon that includes the "purple bacteria and their relatives". Int J Syst Evol Microbiol. 1988;38(3):321-5.

46. Garrity GM, Bell JA, Phylum Lilburn T. XIV. Proteobacteria phyl nov. In: Brenner DJ, Krieg NR, Stanley JT, Garrity GM, editors. Bergey's manual of Sytematic bacteriology, second edition. Vol. 2 (the Proteobacteria), part C (the Alpha-, Beta-, Delta-, and Epsilonproteobacteria). New York: Springer; 2005. p. 1.

47. List of new names and new combinations previously effectively, but not validly, published. List no. 106. Int J Syst Evol Microbiol. 2006;56:677.

48. Ashburner M, Ball CA, Blake JA, Botstein D, Butler H, Cherry JM, et al. Gene ontology: tool for the unification of biology. The gene ontology consortium. Nat Genet. 2000;25:25-9 PMID: 10802651.

Ready to submit your research? Choose BMC and benefit from:

- fast, convenient online submission

- thorough peer review by experienced researchers in your field

- rapid publication on acceptance

- support for research data, including large and complex data types

- gold Open Access which fosters wider collaboration and increased citations

- maximum visibility for your research: over $100 \mathrm{M}$ website views per year

At $\mathrm{BMC}$, research is always in progress.

Learn more biomedcentral.com/submissions 